\title{
Rozdział 2
}

\section{Zachowania oszczędnościowe studentów w Lublinie}

Anna Magdalena Korzeniowska*

\section{Wprowadzenie}

Jednym z warunków bezpieczeństwa finansowego kraju są zachowania uczestników rynku finansowego zapewniające stabilność ekonomiczno-finansową instytucji finansowych. W Polsce rynek finansowy jest silnie ubankowiony, dlatego stabilność banków odgrywa nad wyraz istotną rolę. W erze niskich stóp procentowych, wysokiej konkurencji oraz niskiej lojalności klientów banków szczególnego znaczenia nabiera posiadanie stabilnych źródeł finansowania. Dla banków taką funkcję pełnią depozyty, przede wszystkim te, które pochodzą z sektora niefinansowego, w tym od klientów indywidualnych.

W sytuacji starzenia się polskiego społeczeństwa banki, poszukując nowych rynków oraz by zbudować lojalność klientów, muszą zwrócić uwagę na najmłodsze pokolenia. Nie jest to zadanie łatwe, ponieważ badania wykazują, że zachowania finansowe $w$ grupie osób określanych mianem młodych dorosłych wynikają $\mathrm{w}$ znacznym stopniu $\mathrm{z}$ zachowań zaobserwowanych $\mathrm{w}$ domu rodzinnym ${ }^{1}$, a także z nawyków powstałych w dzieciństwie w zakresie sposobu zaspokajania własnych potrzeb konsumpcyjnych i źródeł ich finansowania².

* Uniwersytet Marii Curie-Skłodowskiej w Lublinie, Wydział Ekonomiczny, Katedra Bankowości.

1 S. Shim, J. Serido, C. Tang, N. Card, Socialization processes and pathways to healthy financial development for emerging young adults, „Journal of Applied Developmental Psychology” 2015, No. 38, s. 29-38 (http://doi.org/10.1016/j.appdev, dostęp: 2.01.2015).

2 A. Otto, Saving in childhood and adolescence: Insights from developmental psychology, „Economics of Education Review” 2012, No. 33, s. 8-18 (http://doi.org/10.1016/j.econedurev, dostęp: 5.09.2012). 
Celem opracowania jest zatem zbadanie, jaki jest poziom oszczędzania wśród określonej grupy młodych dorosłych w Polsce i jakie czynniki oddziałują na ich skłonność do oszczędzania.

\subsection{Skłonność do oszczędzania młodych dorosłych Polaków na tle krajów Unii Europejskiej}

Aktualny wskaźnik ubankowienia w Polsce wynosi ok. 77\%, przy czym jest zróżnicowany w poszczególnych grupach wiekowych. Zmienia się także jego wartość w czasie. W 2009 roku w grupie wiekowej od 18do 29 lat wynosił on $74 \%$ i był niższy od właściwego dla grup wiekowych od 30 do 44 lat (87\%) i od 45 do 59 lat $(79 \%)^{3}$. Z kolei w 2013 roku konto osobiste najczęściej posiadały osoby w wieku 35-44 lat $(96 \%)^{4}$. Niewiele mniejszy był wskaźnik ubankowienia wśród osób w wieku 25-34 lat (93\%) oraz 45-54 lat (88\%). Najrzadziej konto osobiste posiadały osoby w wieku 55 lat i więcej. Ubankowienie w najmłodszej badanej grupie, tzw. młodych dorosłych, czyli 18-24-latków, wynosiło 70\%. Porównując te dane ze wskaźnikami charakteryzującymi społeczeństwa w krajach wysoko rozwiniętych, należy stwierdzić, że nie jest to poziom zadowalający. Ubankowienie w Polsce jest wyraźnie niższe niż średnia dla Unii Europejskiej, nie wspominając o krajach skandynawskich, gdzie wynosi 99-100\%.

Bank Światowy od 2011 roku prowadzi badania dotyczące wykorzystania produktów finansowych w większości krajów świata. Na tej podstawie obliczany jest poziom włączenia finansowego. Ankiety dotychczas były realizowane dwukrotnie: w 2011 i w 2014 roku. Na rysunku 2.1 przedstawiono poziom ubankowienia w najmłodszej grupie wiekowej podlegającej analizie, czyli osób w wieku 15-25 lat.

Jak widać, pod względem ubankowienia tej grupy w 2014 roku Polska znalazła się na 20. miejscu spośród 28 krajów Unii Europejskiej. Jeszcze gorzej młodzi Polacy wypadają na tle swoich rówieśników z Unii Europejskiej, jeśli chodzi o gromadzenie oszczędności (rys. 2.2). Jedynie 17,31\% ankietowanych przez Bank Światowy w 2011 roku i 12,22\% w 2014 roku z grupy wiekowej 15-25 lat deklarowało posiadanie oszczędności w instytucjach finansowych, w tym w bankach. Średnia dla krajów UE wynosiła odpowiednio 43,08\% i 53,71\%. Ponadto w 20 krajach odnotowano wzrost liczby oszczędzających pomiędzy obiema rundami badania, natomiast w Polsce wystąpił spadek o ponad 5 punktów procentowych.

3 Koźliński T. Porównanie wyników badań ubankowienia Polaków przeprowadzonych przez NBP w 2006 i 2009 r., NBP, Warszawa, grudzień 2009 r.

4 Tenże, Zwyczaje płatnicze Polaków, NBP, Departament Systemu Płatniczego, maj 2013 r. 
Rysunek 2.1. Wskaźnik ubankowienia (posiadanie rachunku w instytucjach finansowych) w grupie mtodych dorosłych (15-25 lat) (w \%)

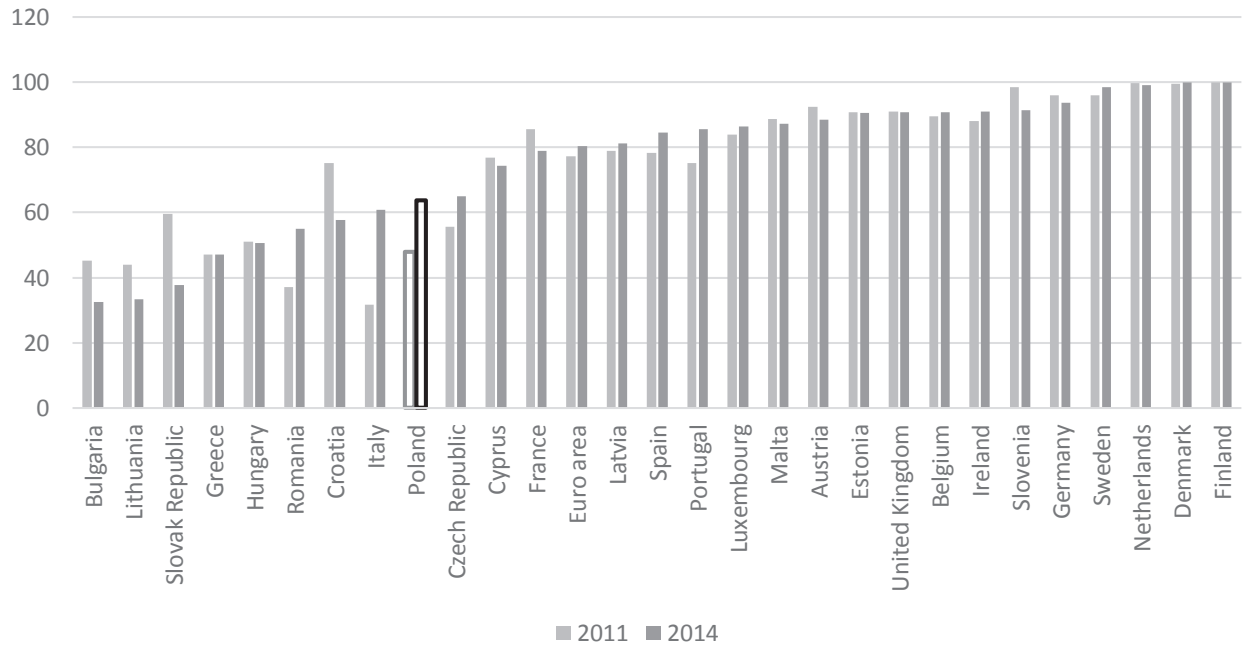

Źródło: opracowanie własne na podstawie Global Findex (Global Financial Inclusion Database), http://databank.worldbank.org (dostęp: 15.06.2016).

Rysunek 2.2. Oszczędzający w instytucjach finansowych w grupie młodych dorostych (15-25 lat) (w \%)

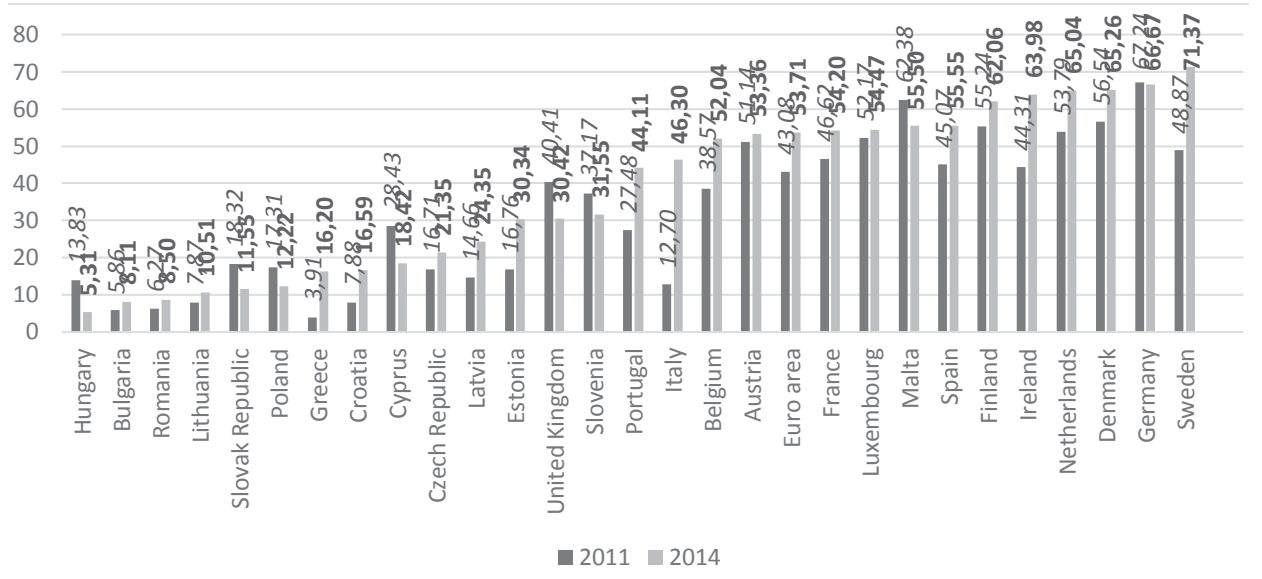

Źródło: opracowanie własne na podstawie Global Findex (Global Financial Inclusion Database), http://databank.worldbank.org (dostęp: ?).

Przedstawione powyżej dane sprawiają pewne trudności interpretacyjne. Grupa wiekowa 15-25 lat jest w Polsce silnie zróżnicowana. Należą do niej uczniowie gimnazjów, szkół średnich, studenci oraz młode osoby, które po wejściu w dorosłość podjęły pracę. Rozmaite możliwości pozyskiwania dochodów oraz różnice w stylu życia sprawiają, że grupa ta nie zachowuje się jednolicie na rynku finansowym. 


\subsection{Oszczędzanie według studentów w Lublinie}

\subsubsection{Dobór próby}

Według Narodowego Spisu Powszechnego w 2011 roku w Polsce było 2314 tys. osób w wieku 15-19 lat, co stanowiło 6\% ogółu ludności kraju. Ponad połowa z nich w kolejnych latach podjęła naukę w szkołach wyższych. W roku akademickim 2014/2015 w 434 szkołach wyższych wszystkich typów kształciło się 1469,4 tys. studentów. Ponieważ studenci stanowią ponad połowę populacji w swojej grupie wiekowej, w dalszych badaniach skupiono się wyłącznie na nich.

Lublin jest dziewiątym miastem w Polsce pod względem liczby mieszkańców i jednym z większych ośrodków akademickich. Znajduje się w nim pięć uczelni publicznych (w tym Katolicki Uniwersytet Lubelski) oraz 4 uczelnie niepubliczne. Według danych Urzędu Miasta Lublina studenci stanowią ok. 20\% mieszkańców. Badanie zachowań finansowych studentów Lublina przeprowadzono w okresie marzec-kwiecień 2015 roku z wykorzystaniem ankiety umieszczonej na stronie https://surveymonkey.net/ (CAWI). Próba badawcza objęła 852 osoby studiujące w Lublinie. Dobór próby był warstwowy z uwzględnieniem liczby studentów studiujących na poszczególnych uczelniach oraz trybu studiowania (studia stacjonarne/niestacjonarne).

\subsubsection{Style oszczędzania respondentów}

Spośród respondentów 383 kobiety i 201 mężczyzn zadeklarowało gromadzenie oszczędności. Pozostałe osoby świadomie nie oszczędzają (170 osób) lub całe dochody przeznaczają na bieżącą konsumpcję (76).

Porównując style oszczędzania kobiet i mężczyzn w analizowanej grupie, można stwierdzić, że mężczyźni są bardziej nastawieni na oszczędzanie. Większy odsetek mężczyzn niż kobiet realizuje oszczędzanie resztowe i planowe. Natomiast spośród kobiet większy odsetek deklaruje świadome niepodejmowanie oszczędzania. Test średnich dla prób niezależnych wykazuje jednak brak statystycznie istotnych różnic pomiędzy płciami w tym zakresie.

\subsubsection{Wielkość oszczędności}

W grupie badanej 580 respondentów zadeklarowało wielkość posiadanych oszczędności liczoną wielkością dochodów. Spośród nich 40,7\% wskazało, że ich oszczędności są równe jednomiesięcznym dochodom, a kolejne 29,8\%, że mieszczą się w przedziale 1-3 miesięcznych dochodów. Jedynie 3,3\% respondentów wskazało, że zgromadzone przez nich oszczędności są większe od dochodów 
Rysunek 2.3. Style oszczędzania studentów

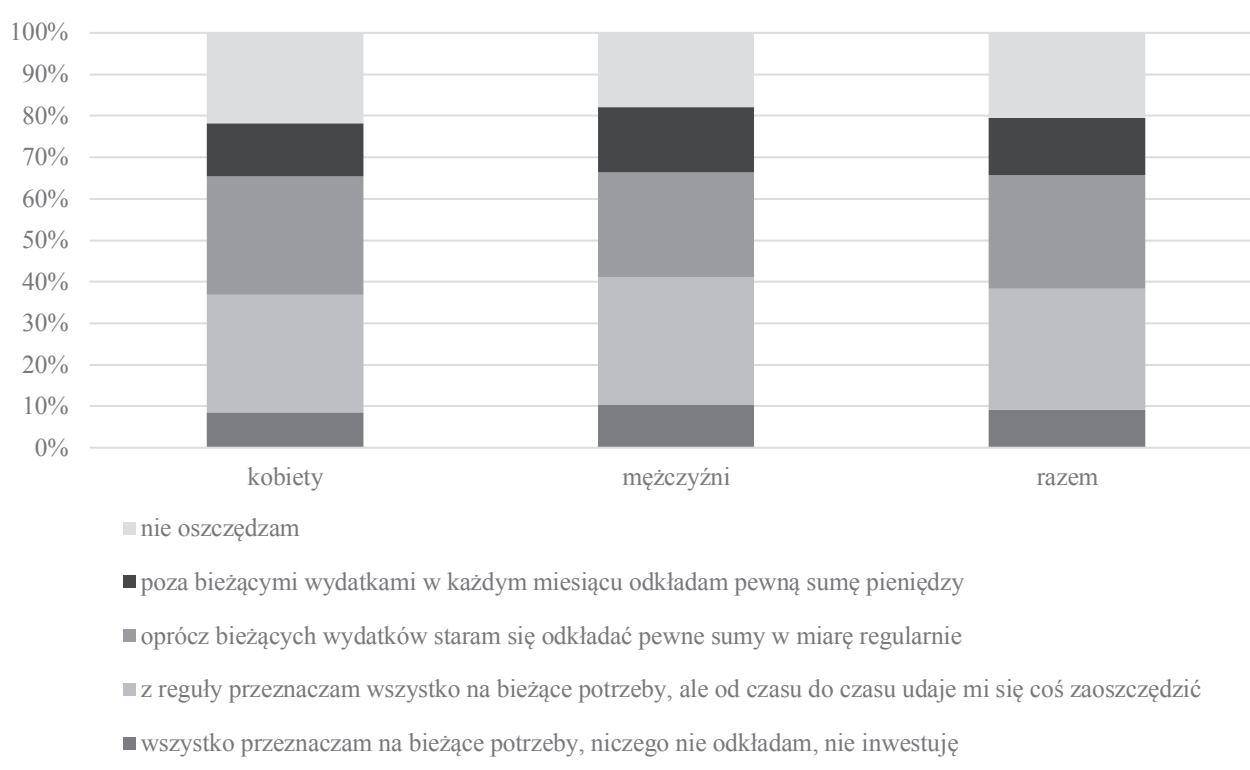

Źródło: opracowanie własne na podstawie przeprowadzonych badań, $n=830$.

rocznych. Z kolei 18,4\% posiadało oszczędności o wartości 3-6 miesięcznych dochodów i 7,8\% o wartości 6-12 miesięcznych dochodów. Porównując to z danymi dotyczącymi polskiego społeczeństwa pochodzącymi z badań Diagnozy społecznej $2013^{5}$, można stwierdzić, że przeciętna wartość oszczędności studentów jest niższa od oszczędności zgromadzonych przez gospodarstwa domowe (tab. 2.1), chociaż odsetek respondentów deklarujących posiadanie oszczędności - 38,5\% - jest niższy od tego w grupie badanych studentów z Lublina.

Tabela 2.1. Struktura oszczędzających Polaków pod względem wartości zgromadzonych oszczędności w 2013 roku

\begin{tabular}{|c|c|c|c|c|c|c|}
\hline $\begin{array}{l}\text { Posiadający } \\
\text { oszczędno- } \\
\text { ści równe } \\
\text { miesięcz- } \\
\text { nym } \\
\text { dochodom }\end{array}$ & $\begin{array}{l}\text { Posiadający } \\
\text { oszczędno- } \\
\text { ści równe } \\
1-3 \text { mie- } \\
\text { sięcznym } \\
\text { dochodom }\end{array}$ & \begin{tabular}{|l|} 
Posiadający \\
oszczędno- \\
ści równe \\
$3-6$ mie- \\
sięcznym \\
dochodom
\end{tabular} & $\begin{array}{l}\text { Posiadający } \\
\text { oszczędno- } \\
\text { ści równe } \\
6-12 \text { mie- } \\
\text { sięcznym } \\
\text { dochodom }\end{array}$ & $\begin{array}{l}\text { Posiadający } \\
\text { oszczęd- } \\
\text { ności } \\
\text { przekracza- } \\
\text { jące roczne } \\
\text { dochody }\end{array}$ & $\begin{array}{l}\text { Trudno } \\
\text { powiedzieć }\end{array}$ & $\begin{array}{l}\text { Posiadający } \\
\text { oszczęd- } \\
\text { ności } \\
\text { przekracza- } \\
\text { jące 3-letnie } \\
\text { dochody }\end{array}$ \\
\hline $25 \%$ & $29,1 \%$ & $20,1 \%$ & $11,7 \%$ & $4,6 \%$ & $8,1 \%$ & $1,4 \%$ \\
\hline
\end{tabular}

Źródło: Diagnoza społeczna 2013.

5 Rada Monitoringu Społecznego, Diagnoza społeczna: zintegrowana baza danych, 2015, www. diagnoza.com (dostęp: 17.01.2015). 


\subsubsection{Stosowane instrumenty oszczędnościowe}

Gospodarstwa domowe mogą stosować różne instrumenty oszczędnościowe, a także dywersyfikować swój portfel oszczędności. W prowadzonych badaniach zapytano zatem studentów, w jakich instrumentach lokują swoje oszczędności i ponownie porównano dane z wynikami Diagnozy społecznej 2013. W obu przypadkach respondenci mogli wskazać wiele odpowiedzi. Jeśli chodzi o gospodarstwa domowe, dominującym instrumentem stosowanym do lokowania oszczędności były lokaty terminowe w PLN, z których korzystało 65,4\% oszczędzających. Niewiele mniejszym zainteresowaniem cieszyła się gotówka, którą jako instrument oszczędzania traktowało ponad 47,5\% osób deklarujących posiadanie oszczędności. Z pozostałych instrumentów korzystało nie więcej niż 10\% oszczędzających. $\mathrm{Z}$ kolei badani studenci uczelni lubelskich przede wszystkim utrzymywali swoje walory w formie płynnej. Ponad 34\% respondentów wskazywało, że posiadane oszczędności przechowuje w gotówce lub na rachunku oszczędnościowo-rozliczeniowym (tab. 2.2).

Tabela 2.2. Struktura populacji oszczędzających Polaków pod względem wartości zgromadzonych oszczędności w 2013 roku

\begin{tabular}{|l|c|c|c|}
\hline \multirow{2}{*}{ Forma oszczędzania } & \multicolumn{2}{|c|}{ Obserwacje } & \multirow{2}{*}{$\begin{array}{c}\text { Diagnoza } \\
\text { spoteczna 2013 }\end{array}$} \\
\cline { 2 - 3 } & \multicolumn{2}{|c|}{ Uwzględnione } & \\
\cline { 2 - 3 } & $\mathbf{N}$ & $34,2 \%$ & $47,6 \%$ \\
\hline Gotówka & 291 & $34,5 \%$ & b.d. \\
\hline $\begin{array}{l}\text { Rachunek oszczędnościowo- } \\
\text {-rozliczeniowy }\end{array}$ & 294 & $13,0 \%$ & $65,4 \%$ \\
\hline Lokata terminowa & 111 & $1,3 \%$ & $8,1 \%$ \\
\hline $\begin{array}{l}\text { Polisa ubezpieczeniowa } \\
\text { z funduszem kapitałowym }\end{array}$ & 11 & $0,7 \%$ & $1,8 \%$ \\
\hline Akcje & 6 & $0,8 \%$ & $2,0 \%$ \\
\hline Obligacje & 7 & $1,8 \%$ & $5,5 \%$ \\
\hline Fundusze inwestycyjne & 15 & & \\
\hline
\end{tabular}

Źródto: opracowanie własne na podstawie wyników badań ankietowych i Diagnozy społecznej 2013.

Zainteresowanie lokatami terminowymi wykazało jedynie 13\% oszczędzających. Także niższy odsetek respondentów deklarował posiadanie polis ubezpieczeniowych, akcji, obligacji i funduszy inwestycyjnych. Skupienie się na płynnych środkach oszczędzania w znacznym stopniu może wynikać z tego, że studenci nie planują tego procesu. Jak już wcześniej wskazano, 29,2\% respondentów zadeklarowało, że oszczędza wtedy, gdy na koniec miesiąca zostaną jakieś środki. Natomiast jako alternatywne instrumenty przechowywania oszczędności 5 osób wskazało posiadanie metali szlachetnych, głównie złotych i srebrnych monet. 


\subsubsection{Cele oszczędzania}

Porównując cele oszczędzania, również znajdziemy wyraźne różnice pomiędzy grupą studentów a ogółem społeczeństwa. Wedle Diagnozy społecznej 2013 priorytetowym celem oszczędzania jest dla Polaków zapewnienie sobie bezpieczeństwa finansowego w sytuacjach losowych (66\% respondentów w 2013 r.), a następnie zabezpieczenie środków finansowych na starość $(35,9 \%)$. Pozostałe istotne cele to leczenie $(29,6 \%)$, remont domu lub mieszkania $(26,3 \%)$, wypoczynek $(24,7 \%)$, przyszłość dzieci $(23,1 \%)$, zakup dóbr trwałych $(21,3 \%)$. Ponad $10 \%$ respondentów oszczędza na rehabilitację i pokrycie opłat stałych. Brak celu oszczędzania w 2013 roku wskazało 9,7\% gromadzących środki.

Studenci jako priorytetowy cel oszczędzania wskazują przyszłą konsumpcję. Oszczędzanie na zaplanowany z góry cel, np. zakup samochodu, wypoczynek itp. jako powód gromadzenia środków wskazało 31,2\% badanych. Na drugim miejscu znalazło się zapewnienie funduszy na przyszłość (24,9\%). Blisko $1 / 5$ respondentów gromadzi oszczędności, żeby zabezpieczyć się od zdarzeń losowych. Tyle samo realizuje oszczędzanie resztowe. Analizując odpowiedzi badanych z uwzględnieniem trybu studiowania, poziomu studiów i ich sytuacji rodzinnej, zauważono, że dla respondentów studiujących na studiach odpłatnych oraz w trybie niestacjonarnym, a także na studiach magisterskich i dla osób będących w stałym związku zapewnienie sobie funduszy na przyszłość stanowi priorytetowy cel oszczędzania (tab. 2.3). Zabezpieczenie na czarną godzinę częściej wybierają kobiety, studenci studiów bezpłatnych i studenci studiów licencjackich. Natomiast oszczędzanie resztowe częściej jest realizowane przez mężczyzn, studentów studiów bezpłatnych, licencjackich i stacjonarnych.

\subsubsection{Przyczyny gromadzenia oszczędności}

W celu ustalenia czynników zachęcających studentów do oszczędzania, poproszono ich o ocenę wybranych przyczyn w skali od 1 (brak wpływu) do 5 (bardzo duży wpływ danego czynnika na decyzje o oszczędzaniu). Analiza wykazała, że wszystkie czynniki są ze sobą skorelowane dodatnio (korelacja istotna na poziomie 0,01). Najniższą średnią ocenę - 2,96, przy równocześnie najwyższym odchyleniu standardowym wynoszącym 1,52 - respondenci przypisali dobrej koniunkturze rynkowej. Na drugim od końca miejscu uplasowała się atrakcyjna oferta oszczędnościowa (średnia 3,18, odchylenie 1,49). Z kolei najwyższą ocenę $(3,83)$ przy najmniejszym odchyleniu standardowym $(1,16)$ przypisano jasno zdefiniowanym celom oszczędzania. Najwyższe oceny temu czynnikowi nadawali mężczyźni, osoby studiujące na studiach płatnych i niestacjonarnych oraz osoby stanu wolnego (tab. 2.4). Dla kobiet, osób w stałym związku, osób studiujących na studiach stacjonarnych, licencjackich i magisterskich najważniejszym czynnikiem okazały się możliwości finansowe, w tym wysokość zarobków studenta. W grupie osób będących w stałym związku czynnik ten oceniono na 4,01. 


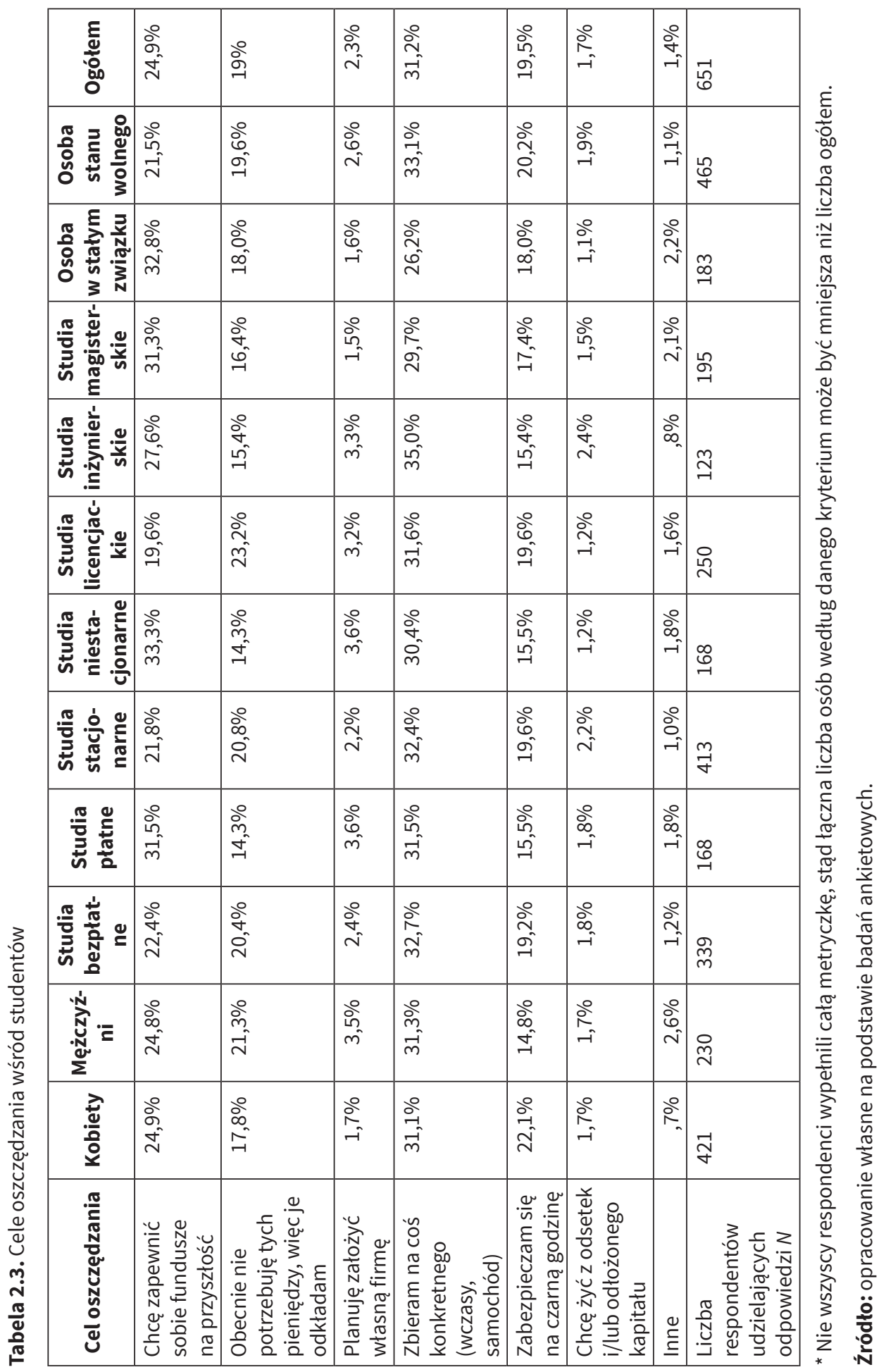




\begin{tabular}{|c|c|c|c|c|c|c|c|c|}
\hline 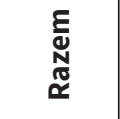 & $\overrightarrow{\hat{n}}$ & $\begin{array}{l}\infty \\
\infty \\
m\end{array}$ & $\begin{array}{l}\text { In } \\
\text { m. }\end{array}$ & 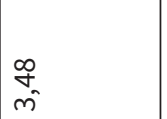 & $\begin{array}{c}m \\
\infty \\
m \\
m\end{array}$ & $\begin{array}{l}\text { o } \\
\text { m. }\end{array}$ & ڤ̊ & \\
\hline 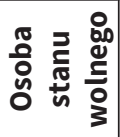 & $\begin{array}{l}\hat{6} \\
\dot{m}\end{array}$ & $\underset{m}{\mathbb{N}}$ & $\begin{array}{l}\hat{f} \\
\text { m }\end{array}$ & $\stackrel{\mathcal{F}}{\tilde{m}}$ & $\frac{\infty}{\stackrel{\infty}{m}}$ & 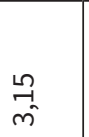 & ๙̃ & $\begin{array}{l}\text { I } \\
\text { m. }\end{array}$ \\
\hline 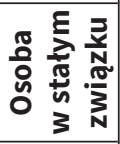 & $\begin{array}{l}\dot{\infty} \\
\text { m }\end{array}$ & $\begin{array}{l}-1 \\
0 \\
\sigma^{\prime}\end{array}$ & $\begin{array}{l}\overrightarrow{0} \\
\dot{m}\end{array}$ & $\begin{array}{l}\tilde{6} \\
\tilde{m}\end{array}$ & $\begin{array}{l}\text { ñ } \\
\text { m. }\end{array}$ & $\stackrel{\text { m}}{m}$ & $\begin{array}{l}8 \\
\text { m }\end{array}$ & $\begin{array}{l}8 \\
\text { mे }\end{array}$ \\
\hline 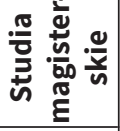 & $\begin{array}{l}\tilde{G} \\
\text { m }\end{array}$ & $\begin{array}{l}\text { D } \\
\infty \\
\text { m }\end{array}$ & $\stackrel{\vec{n}}{\text { m }}$ & $\begin{array}{l}\mathscr{q} \\
\dot{m}\end{array}$ & $\begin{array}{l}\stackrel{2}{\infty} \\
\infty \\
m\end{array}$ & $\stackrel{\text { N }}{m}$ & $\begin{array}{l}\infty \\
\stackrel{\infty}{2} \\
\sim\end{array}$ & $\begin{array}{l}8 \\
\text { m }\end{array}$ \\
\hline 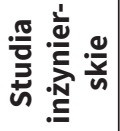 & $\begin{array}{l}\stackrel{P}{m^{2}} \\
m\end{array}$ & $\underset{m}{\mathbb{N}}$ & $\stackrel{\vec{n}}{\mathrm{~m}}$ & $\stackrel{\substack{f \\
m}}{m}$ & $\begin{array}{l}\hat{N} \\
\dot{m}\end{array}$ & $\begin{array}{c}\hat{D} \\
\text { min }\end{array}$ & $\begin{array}{c}\infty \\
\infty \\
\sim \\
\sim\end{array}$ & $\stackrel{\vec{T}}{m}$ \\
\hline 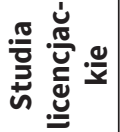 & $\begin{array}{l}\infty \\
\infty \\
m \\
m\end{array}$ & $\begin{array}{l}\widehat{N} \\
\infty \\
m\end{array}$ & $\begin{array}{l}\stackrel{\circ}{n} \\
m\end{array}$ & 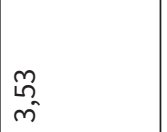 & $\begin{array}{l}m \\
\infty \\
\tilde{m}\end{array}$ & $\stackrel{\tilde{m}}{m}$ & $\begin{array}{l}8 \\
\text { m }\end{array}$ & $\begin{array}{l}\text { 으 } \\
\text { in }\end{array}$ \\
\hline 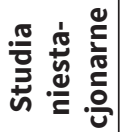 & $\begin{array}{l}\mathscr{0} \\
\dot{m} \\
\dot{m}\end{array}$ & $\overrightarrow{\hat{n}}$ & $\begin{array}{l}\hat{m} \\
\text { m. }\end{array}$ & $\begin{array}{l}\stackrel{\mathscr{N}}{\mathrm{m}} \\
\mathrm{m}\end{array}$ & $\underset{\sim}{\stackrel{N}{m}}$ & $\begin{array}{l}\overrightarrow{1} \\
m\end{array}$ & $\begin{array}{l}0 \\
\infty \\
i \\
i\end{array}$ & $\stackrel{\stackrel{\sim}{N}}{m}$ \\
\hline 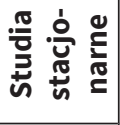 & $\begin{array}{l}q \\
\stackrel{m}{m}\end{array}$ & $\begin{array}{l}\infty \\
\infty \\
m \\
m\end{array}$ & $\stackrel{\stackrel{\infty}{n}}{m}$ & $\begin{array}{l}\stackrel{L}{n} \\
\text { m. }\end{array}$ & $\begin{array}{l}\infty \\
\infty \\
m \\
m\end{array}$ & 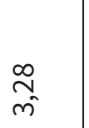 & $\begin{array}{l}\qquad \\
0 \\
m\end{array}$ & $\begin{array}{l}6 \\
\text { o } \\
\text { in }\end{array}$ \\
\hline 旁 & $\underset{m}{\stackrel{N}{N}}$ & $\stackrel{\hat{N}}{\tilde{m}^{-}}$ & $\begin{array}{l}\vec{y} \\
m\end{array}$ & $\stackrel{\stackrel{\overbrace{}}{2}}{\mathrm{~m}}$ & $\begin{array}{l}q \\
m \\
m\end{array}$ & $\stackrel{\vec{n}}{\text { m }}$ & $\begin{array}{l}\text { g } \\
\text { i }\end{array}$ & $\stackrel{m}{\stackrel{m}{m}}$ \\
\hline 竞 芫 & $\begin{array}{c}\infty \\
\infty \\
m\end{array}$ & $\begin{array}{l}\sigma^{-1} \\
\text { n. }\end{array}$ & $\begin{array}{l}\stackrel{n}{n} \\
m\end{array}$ & $\begin{array}{l}\text { on } \\
\text { ñ. }\end{array}$ & $\begin{array}{l}\infty \\
\infty \\
m\end{array}$ & $\begin{array}{l}\vec{m} \\
m\end{array}$ & $\vec{m}$ & $\stackrel{\text { 글 }}{\text { m }}$ \\
\hline 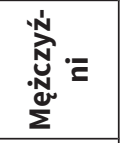 & 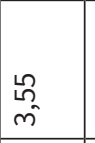 & $\begin{array}{l}\stackrel{n}{\kappa} \\
m \\
m\end{array}$ & $\begin{array}{c}\infty \\
m \\
m\end{array}$ & $\begin{array}{l}\mathscr{m} \\
\text { m }\end{array}$ & $\begin{array}{l}\hat{\infty} \\
\infty \\
m\end{array}$ & $\begin{array}{l}\text { ్ } \\
\text { m. }\end{array}$ & $\begin{array}{l}8 \\
\text { m }\end{array}$ & $\stackrel{\stackrel{\sim}{N}}{m^{2}}$ \\
\hline $\begin{array}{l}\overrightarrow{0} \\
\frac{0}{0} \\
\dot{0}\end{array}$ & $\begin{array}{l}\infty \\
\infty \\
m\end{array}$ & $\begin{array}{l}m \\
\infty \\
m \\
m\end{array}$ & $\begin{array}{l}\text { م્ } \\
\text { mે }\end{array}$ & $\begin{array}{l}\vec{n} \\
\text { m }\end{array}$ & $\begin{array}{l}-1 \\
\infty \\
m\end{array}$ & $\begin{array}{l}\infty \\
\stackrel{\infty}{c} \\
m\end{array}$ & 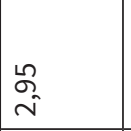 & ণ \\
\hline 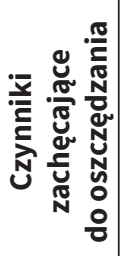 & 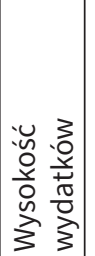 & 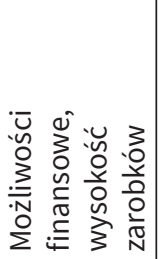 & 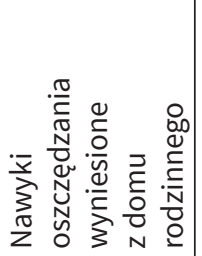 & 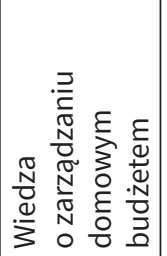 & 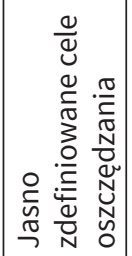 & 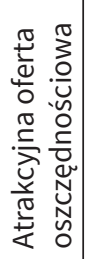 & 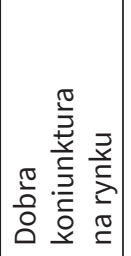 & 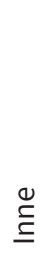 \\
\hline
\end{tabular}




\subsubsection{Zależność oszczędności studentów od ich sytuacji społeczno-ekonomicznej}

W dalszym etapie badania przyjęto założenie, że na wartość dochodów zgromadzonych przez studentów w Lublinie wpływają czynniki wymienione w ankiecie. Pozytywnie udało się zweryfikować tylko jedną z tak sformułowanych hipotez, wskazującą, że na wysokość oszczędności wpływają nawyki oszczędzania wyniesione $\mathrm{z}$ domu rodzinnego. Wpływ pozostałych czynników okazał się nieistotny statystycznie. Ponadto analiza wykazała, że czynnikiem wpływającym na poziom zgromadzonych oszczędności jest sytuacja rodzinna respondenta - stan wolny lub przebywanie w stałym związku. Doprowadziło to do sformułowania funkcji regresji liniowej w postaci:

$$
Y=1,989+0,126 X-0,234 Z
$$

gdzie:

$Y$ - wielkość oszczędności,

$X$ - nawyki oszczędzania wyniesione z domu oceniane w skali od 1 - brak wpływu do 5 - wpływ bardzo duży,

$Z$ - sytuacja rodzinna określana jako 1 - w stałym związku, 2 - stan wolny.

\subsection{Wnioski z przeprowadzonej analizy}

Podsumowując przeprowadzone rozważania, można wysnuć kilka wniosków na temat zachowań studentów w zakresie gromadzenia oszczędności. Po pierwsze, świadome decyzje o oszczędzaniu podejmuje niewielki odsetek studentów $(13,7 \%)$. Przy czym bardziej zdecydowane działania podejmują mężczyźni. Zarówno w grupie osób deklarujących oszczędzanie regularne, jak i w grupie deklarującej przeznaczanie całości środków na bieżącą konsumpcję, można zaobserwować przewagę mężczyzn.

Po drugie, poziom oszczędności w tej grupie społecznej jest stosunkowo niski. $Z$ reguły nie przekracza dochodów trzymiesięcznych. Oznacza to, że przeciętny student nie posiada finansowego buforu bezpieczeństwa na wypadek braku dochodów, chociaż niemal 1/4 oszczędzających deklaruje, że robi to w celu zapewnienia sobie funduszy na przyszłość, a kolejne 19,5\% oszczędza na tzw. czarną godzinę.

Po trzecie, występuje wyraźna rozbieżność pomiędzy strukturą aktywów finansowych, w których lokowane są oszczędności studentów, a celami oszczędzania. Ponad 31\% oszczędzających studentów wskazała, że ich celem oszczędzania jest zakup określonych dóbr i usług. Z drugiej strony głównymi instrumentami finansowymi wykorzystywanymi w procesie oszczędzania są: gotówka i rachunki 
oszczędnościowo-rozliczeniowe. Spośród osób, które wskazały, że ich oszczędności są przetrzymywane w formie gotówkowej, 110 zadeklarowało oszczędzanie na konkretny cel, 58 - na zabezpieczenie przyszłości, 62 - na tzw. czarną godzinę, a 73 obecnie nie potrzebują środków, więc je odkładają. W grupie przetrzymującej oszczędności na ROR 89 osób deklarowało oszczędzanie na określony cel, 82 na zabezpieczenie przyszłych wydatków, 60 na tzw. czarną godzinę i 56 oszczędzało bez konkretnego celu. Tylko 44 osoby wskazały, że ich celem oszczędzania jest zabezpieczenie przyszłości i w tym celu korzystają z lokaty terminowej, a 25 wykorzystuje lokaty do oszczędzania na określony wydatek w przyszłości i 24 osoby lokują w ten sposób oszczędności, które nie mają określonego celu przeznaczenia.

Jeśli chodzi o ocenę ważności poszczególnych czynników wpływających na podejmowanie decyzji o oszczędzaniu, respondenci za najistotniejsze uznali: zdefiniowanie celów oszczędzania, atrakcyjność oferty instytucji finansowych oraz swoje możliwości finansowe pozwalające im na przeznaczanie części dochodów na cele inne niż konsumpcja bieżąca. Spośród siedmiu ocenianych czynników nawyki wyniesione przez respondentów z domu rodzinnego zostały umiejscowione dopiero na piątym miejscu. Jednak badając zależność przedstawionych ocen z zadeklarowaną wartością posiadanych oszczędności, czyli badając faktyczne, a nie deklarowane zachowania respondentów, potwierdzono teorie przedstawiane w badaniach międzynarodowych, że jednym z najważniejszych czynników wpływających na oszczędzanie przez młode pokolenie są doświadczenia wyniesione $\mathrm{z}$ domu rodzinnego. Drugim istotnym elementem okazała się sytuacja rodzinna respondentów - czy są w stałym związku, czy stanu wolnego.

\section{Podsumowanie}

Przeprowadzone badania wskazują na istotne problemy, na jakie mogą natrafić banki, próbując powiększyć w przyszłości swoją potencjalną dostępność do taniego pieniądza w postaci depozytów osób fizycznych. Konieczne jest zatem podejmowanie działań edukacyjnych skierowanych do dwóch grup klientów: osób młodych, w tym niepełnoletnich, oraz pokolenia 40+, czyli ich rodziców. Obie grupy należy edukować w zakresie możliwości wykorzystywania produktów bankowych przez młode osoby oraz korzyści, jakie przynosi systematyczne oszczędzanie w połączeniu z odpowiednio do niego dobranymi instrumentami finansowymi. W ten sposób możliwe będzie także osiągnięcie dodatkowych dwóch celów. Po pierwsze, wychowanie lojalnych klientów. Po drugie, zwiększenie liczby produktów, z których korzystają poszczególni klienci. 


\section{Bibliografia}

Global Findex (Global Financial Inclusion Database), http://databank.worldbank.org (dostęp: 15.06.2016).

Koźliński T., Porównanie wyników badań ubankowienia Polaków przeprowadzonych przez NBP w 2006 i 2009 r., NBP, Warszawa, grudzień 2009 r.

Koźliński T., Zwyczaje płatnicze Polaków, NBP, Departament Systemu Płatniczego, Warszawa, maj $2013 \mathrm{r}$.

Otto A., Saving in childhood and adolescence: Insights from developmental psychology, „Economics of Education Review” 2012, No. 33, s. 8-18 (http://doi.org/10.1016/j.econedurev, dostęp: 5.09.2012).

Rada Monitoringu Społecznego, Diagnoza społeczna: zintegrowana baza danych, 2015, www.diagnoza.com (dostęp:17.01.2015).

Shim S., Serido J., Tang C., Card N., Socialization processes and pathways to healthy financial development for emerging young adults, „Journal of Applied Developmental Psychology” 2015, No. 38, s. 29-38 (http://doi.org/10.1016/j.appdev, dostęp: 2.01.2015).

\section{ZACHOWANIA OSZCZĘDNOŚCIOWE STUDENTÓW W LUBLINIE}

\section{Streszczenie:}

Celem pracy było zbadanie, jaki jest poziom oszczędzania wśród wybranej grupy młodych dorosłych w Polsce i jakie czynniki oddziałują na ich skłonność do oszczędzania. Analiza została oparta na badaniach przeprowadzonych na grupie studentów różnych uczelni w Lublinie. Rezultaty wskazują na niską skłonność do oszczędzania wśród młodych dorosłych, co z kolei prognozuje problemy dla rynku finansowego w przyszłości, ponieważ niskie oszczędności spowalniają rozwój i wzrost gospodarczy.

Słowa kluczowe: młodzi dorośli, zachowania oszczędnościowe, oszczędności gospodarstw domowych

\section{SAVING BEHAVIOUR OF STUDENTS' IN LUBLIN}

\section{Summary:}

The paper aims at examining saving level among selected group of young adults in Poland as well as factors influencing their willingness to save.

The analysis was based on the research conducted on the sample group of students of selected universities in Lublin.

The results achieved suggest that young adults present very low willingness to saving which in turn predicts problems to financial market in the future as low saving slow down development and economic growth.

Keywords: young adults, saving behaviour, household saving 